\title{
「無感ニュートリノ」を求めて
}

\section{Hunt for the sterile neutrino heats up}

ERIC HAND 2010 年3 月 18 日 Vol. 464 (334-335)

www.nature.com/news/2010/100317/full/464334a.html

第四のニュートリノである無感（ステライル）ニュートリノが本当に存在するなら、 天体物理学の最も深刻な問題のいくつかに、解決の糸口を与えるはずだ。

ニュートリノは秘密主義だ。この粒子 は、普通の物質と相互作用したがらな い。そのため、毎日数十億個ものニュー トリノが我々の体を猛スピードで突き 抜けていっても、なんの害も及ぼさな い。逆にいえば、わずか数個であっても、 ニュートリノを検出しようとすれば専 用の巨大検出器が必要になる。天文学 者たちは今、既知のニュートリノより もさらに検出困難なタイプのニュート リノについて、その存在を示唆する証 拠を手にし始めている。ただし、この 第四の無感 (ステライル) ニュートリ

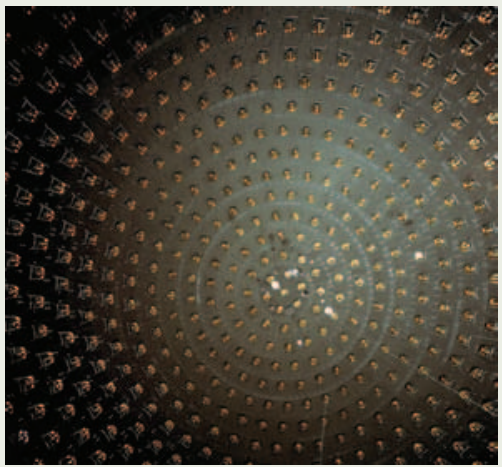

ニュートリノハンター

MiniBooNE 実験は、1280 個の光電 子増倍管を使って、ニュートリノまた は反ニュートリノが巨大なタンクに満 たされた液体の中に飛び込んできたと きに発する「微かな光」をとらえる。 この実験から得られる新しいデータは、 第四のニュートリノがあることを示唆 するかもしれず、そうなれば無感二ュー トリノが実在する可能性が出てくる。
ノを直接検出するのは不可能だと考え られている。

理論家も実験家も 10 年以上前からこ の幽霊粒子に興味をもつていたが、これ をとらえようとする実験は難航を極めて いる。けれども今、宇宙で行われている 2つの観測（1つはマイクロ波、もう 1 つはX線を使ったもの）により、再び 希望がみえてきた。

この無感ニュートリノを同定できれ ば、これまで何度となく検証されてきた 標準モデルを超えて、新しい物理学を垣 間見ることができるだろう。また、天文 学の多くの謎を解き明かす手がかりが 得られ、ひょつとすると、宇宙の質量 の $85 \%$ 占めていると考えられている ダークマター（暗黒物質）の正体さえ説 明できるかもしれない。

ロスアラモス国立研究所（米国ニュー メキシコ州）に所属する William Louis は、「原子核・素粒子物理学と天体物理 学にとって、無感ニュートリノの問題は 非常に重要です」という。彼が 1990 年 代半ばに地上で行った実験は、この幽霊 ニュートリノの存在を示唆する最初期の 証拠の 1 つとなつた。

普通の 3 種類のニュートリノでも ( 次 ページの図を参照)、検出するのは十分 に難しい。これらのニュートリノは「弱 い力」によって物質と相互作用するた め、大量の物質の中を通り抜けても、そ の原子核とはほとんど衝突しない。そこ で物理学者は、ニュートリノをとらえる ために、鉱油または重水を満たしたタン
クを使って検出器を製作する。そしてさ らに、原子炉や粒子加速器や太陽から来 るニュートリノの流れに検出器を集中さ せて、キャッチする確率を高めている。

\section{付き合いの悪い粒子}

1998 年、スイスのジュネーブ近郊に あるヨーロッパ素粒子物理学研究所 (CERN) の加速器を使って行われた実 験結果は、弱い力の作用を受けるニュー トリノが、既知の 3 つのファミリー（フ レーバー）だけであることを示した。し たがって、これら以外のニュートリノは、 弱い力の作用を受けない無感のニュート リノであり、既存の検出器を素通りして しまうことになる。

そもそも、理論家はなぜ、こんな付 き合いの悪い粒子を考え出したのだろ うか？それは、同じ 1998 年に、驚く ベき発見がもう1つあつたからである。 3 種類の普通のニュートリノは、小さい ものの、確かに質量をもつことがわかつ たのだ。

この結果は衝撃的だった。それは単に、 標準モデルではニュートリノには質量が ないとされていたからではない。あるフ レーバーから別のフレーバーへの振動 （変化）の仕方から、3 種類のニュート リノの質量が決定されたが、それらが信 じられないほど小さかったからだ。最も 重いものでも、電子より 7 桁以上軽かつ た。そこで理論家たちは、両者の間には、 ほかのなんらかの粒子（おそらくは無感 ニュートリノ) があるはずだと推測した のである。

このミッシングリンクに関するヒン トをもたらしたのが、ウィルキンソン マイクロ波異方性探査機 (WMAP) だっ た。WMAP は、2001 年以来、ビッグ バンの名残の放射にある微小なゆらぎ の地図を作成している。このゆらぎの パターンには、ビッグバンの直後にあつ た素粒子の混合物に関する手がかりが 残されている。

2010 年 1 月に発表された過去 7 年分 の観測結果は 1 、原始宇宙のニュートリ 
ノのファミリー数が 4 だった可能性が 高いことを示唆した。つまり、あと 1 種類のニュートリノがまだ発見されてい ないことになる。ジョンズ・ホプキンズ 大学 (メリーランド州ボルティモア) の 主任研究員 Charles Bennett は、「ほか にも何かあると主張するのは、たいへん なことです」と語る。観測誤差がまだ 大きく、ニュートリノの種類が最大で 3 である可能性は消えていない、と慎重な 姿勢をとる。「結果は非常に興味深いで すが、気になってしかたがないというほ どではありません」。

より最近の手がかりは、チャンドラ $X$ 線観測衛星からもたらされた。無感 ニュートリノが本当に存在していて十 分な重さがあるなら、これが崩壊して、 より軽いニュートリノへと変化する際 に、かすかな X 線パルスを放つはずだ。 カリフォルニア大学ロサンゼルス校の Alexander Kusenko は、空の中で、多 くのダークマターがあると考えられ、星 やその他の光源がほとんどない領域に 注目した。そして、銀河系の伴銀河で あるウィルマン 1 という薄暗い矮小銀 河からのX線に、予測されたとおりの 兆候を発見したと主張した ${ }^{2}$ 。しかし、 Bennett と同様、Kusenkoも、無感ニュー トリノを発見したと主張するには時期尚 早だという。「すべてがきれいに一致し ているようですが、気をもませますね」。

Kusenko の観測によれば、無感ニュー トリノは、それ自体がダークマター粒子 となりうるほどの重さと量があることに なる。一方、WMAP のデータは、無感 ニュートリノの質量が、理論の予測範囲 の軽い側にあることを示している。カ リフォルニア大学サンディエゴ校天体 物理学・宇宙科学センターの所長であ る George Fuller は、この軽い質量を歓 迎する。それが本当なら、超新星に関す る積年の問題を解決するのに役立つから だ。大質量星が爆発する際、中性子が融 合して鉄よりも重い元素が形成される。 けれどもこのとき、膨大な数のニュート リノも生成する。理論的には、このニュー
トリノが中性子を陽子と電子に変え、そ の融合を抑制すると考えられる。

無感ニュートリノは、この問題を解決 する糸口となる。超新星爆発の際に生成 したニュートリノの一部が無感ニュート リノに変わるなら、これらは中性子と相 互作用することなく飛び去っていくた め、中性子の多くがそのまま残れるから である。「その可能性は高いと思います」 と Fuller はいう。

\section{矛盾する報告}

2010 年 3 月、MINOS (Main Injector Neutrino Oscillation Search) の実験か ら、無感ニュートリノを探す人々を落胆 させるニュースが飛び込んできた ${ }^{3}$ 。こ の実験は、フェルミ国立加速器研究所 (フェルミ研究所、イリノイ州バタヴィ ア）の加速器で生成させたニュートリ ノビームを、735km 離れたミネソタ州 の地下にある MINOS 検出器に向かって 照射し、ニュートリノ振動を検出しょ うとする実験だ。MINOS 実験のデータ は、あるファミリーのニュートリノが無 感ニュートリノに変化しにくいことを示 したのだ。しかし、スポークスマンの Robert Plunkett は、無感ニュートリノ が存在する余地はまだあるという。「今、 無感ニュートリノに関するパラメーター の幅をしぼり込んでいるところです」。

フェルミ研究所ではもう 1 つ、無感 ニュートリノの最初期の手がかりを追跡 する実験が進められている。こちらは もつと明るい展望をもたらす可能性が ある。1993 年から 1998 年まで、Louis と同僚は、液体シンチレーターニュート リノ検出器実験を利用して、167トンの 鉱油に反ニュートリ)（ニュートリノの 反粒子）を照射し、これをとらえようと した。この実験から、ある種類の反ニュー トリノが別の種類の反ニュートリノに変 化する過程についてデータが得られた が、それは 4 種類のフレーバーが存在

していることを示唆していた。

その 10 年後、追試として、フェル ミ研究所でMiniBooNe (Mini Booster

\section{無感ニュートリノの検出を夢見て}

ニュートリノは、普通の物質と「弱い力」 を通じて相互作用する。検出困難な粒 子であり、どんな原子核ともほとんど衝 突することなく地球を突き抜ける。 ニュートリノには 3 つの種類があり、あ る種類から別の種類へと変化 (振動) す ることができる。

いくつかの実験が、第四のニュートリ ノの存在を示唆している。この無感（ス テライル)ニュートリノは、普通のニュー トリノと違って弱い力の作用を受けない ため、その検出はさらに困難になる。

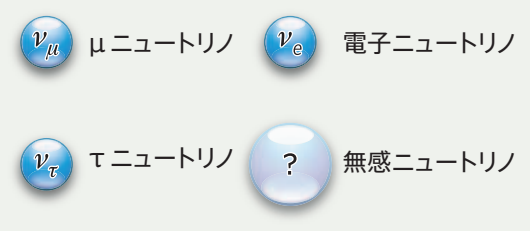

Neutrino Experiment）の実験が行われ た。そのデータからは、第四のニュート リノの存在を裏付ける証拠は全く得られ なかったが、ただこの実験ではニュー トリノビームを使用していたため、結 果をロスアラモスの反ニュートリノの データと比較するのは難しかった。しか し、今回、MiniBooNE で 1 年半にわた る反ニュートリノのデータ収集を終え、 MiniBooNE 実験から違ったパターン がみえてきたのだ(「ニュートリノハン ター」参照)。

世界各地で行われているほかの反 ニュートリノ実験と考え合わせると、こ のデータは、3つの普通のニュートリノ と 1 つの無感ニュートリノという「 $3+1$ モデル」にきれいに一致する、と Louis はいう4。「今年の夏に発表される次の データによって、この検出困難な侵入者 がついにキャッチされたかどうか、より はっきりわかるでしょう」。

(翻訳 : 三枝小夜子)

\footnotetext{
1. Komatsu, E. etal. Preprint at http://arxiv.org/abs/1001.4538v1 (2010).

2. Lowenstein, M. \& Kusenko, A. Preprint at http://arxiv.org/ abs/0912.0552 (2009).

3. Adamson, P.etal. Phys. Rev. D 81, 052004 (2010).

4. Karagiorgi, G., Djurcic, Z., Conrad, J. M., Shaevitz, M. H. \& Sorel, M. Phys. Rev. D 80, 073001(2009).
} 